\title{
O PODER DOS CORONÉIS NO MOVIMENTO DO CONTESTADO
}

\author{
EL PODER DE LOS CORONELES EN EL MOVIMIENTO DEL CONTESTADO
}

\section{THE POWER OF THE COLONELS IN THE CONTESTADO MOVEMENT}

\section{LE POUVOIR DES «COLONELS» AU SEIN DU MOUVEMENT DU CONTESTADO}

\section{DOI: $\underline{10.5533 / 1984-2503-20113206}$}

Eloy Tonon

\section{RESUMO}

O presente trabalho faz uma inserção histórica do nascimento dos coronéis, no período regencial, a consolidação e a legitimação no Segundo Império e a legitimação na República Velha. Mostra a diversidade de poderes constituídos regionalmente, vinculados sempre a uma oligarquia agrária. Apresenta nuances dos coronéis da região Sul do Brasil, o envolvimento dos mesmos com o Movimento ou Guerra do Contestado, acontecimento histórico e social que abalou as estruturas, da região Sul paranaense e Norte, Oeste e Sul catarinense.

Palavras-chave: coronelismo, sertanejos, oligarquias e capital transnacional.

\section{RESUMEN}

El presente trabajo hace una inserción histórica del nacimiento de los coroneles en el período regencial, la consolidación y la legitimación en el Segundo Imperio y República Vieja. Muestra la diversidad de poderes compuestos en la región, siempre asociados a un origen agrario. Presenta matices de los coroneles de la región Sur de Brasil, la participación de los mismos en la Guerra del Contestado, acontecimiento histórico y social que sacudió las estructuras del sur de Paraná y del Norte, Oeste y Sur de Santa Catarina. Palabras-clave: coronelismo, sertanejos, oligarquías y capital transnacional.

\section{ABSTRACT}

This study tells the story of the rise of the colonels during the Regency era, their consolidation during the Second (Brazilian) Empire, and their legitimation in the Old Republic. It 
shows the diversity of regional powers, always linked to an agrarian oligarchy. It presents a nuanced view of the colonels in southern Brazil and their involvement with the Contestado Movement/War, a social and historic event that shook the structures of southern Paraná and northern, western and southern Santa Catarina.

Keywords: colonelism, sertanejos, oligarchy, transnational capital.

\section{RÉSUMÉ}

Le présent travail dépeint le contexte historique de la montée en puissance des « colonels » pendant la Régence, de leur consolidation lors du Second empire et de leur légitimation au sein de la Vieille République. Sera mise en évidence la diversité des pouvoirs régionaux, toujours liés à une oligarchie agraire. Sera également brossé un portrait nuancé des « colonels » du sud du Brésil dans le cadre de leur participation au Mouvement ou Guerre du Contestado, un événement historique et social qui ébranla les structures de la région sud du Paraná et des régions nord, ouest et sud de Santa Catarina. Mots-clés : Colonelisme, sertanejos, oligarchies et capital transnational.

As origens do coronelismo remontam ao período imperial, mais especificamente na transição das regências. Como parte do Exército se colocava sempre ao lado dos manifestantes, a Câmara dos Deputados aprovou uma lei criando a Guarda Nacional, cuja função principal seria a de reprimir as manifestações populares e defender a Constituição. Seus membros eram recrutados entre sujeitos sociais, que tivessem renda anual, de 200 mil-réis nas cidades e 100 mil-réis no interior. Os oficiais superiores, que recebiam o título de coronel, eram, na verdade, os grandes proprietários de terra. A denominação de coronel recaía sobre uma pessoa detentora de riqueza, socialmente bem situada. Eram, portanto, homens que ostentavam riqueza, ocupando funções burocráticas e políticas.

As raízes do coronelismo estão ligadas à dinâmica econômica da monocultura de exportação, pela qual passou a sociedade brasileira, dentro do sistema mercantilista. $\mathrm{Na}$ evolução político-social do Brasil, o coronelismo penetrou profundamente nas atividades partidárias dos municípios. O coronel detentor de uma liderança econômica, resultante de sua riqueza, transforma-se em líder político. Seu poder nascido no império perpetua-se na República dos Governadores. Com o advento do regime republicano, o coronel torna-se dependente de vínculos públicos estaduais, tendo como contrapartida a necessidade do fornecimento de votos, que serão aliciados entre seus empregados e protegidos. Será 
neste momento que o coronel adquire vigor político junto às oligarquias estaduais. A Guarda Nacional foi extinta após a proclamação da República, persistindo a denominação de coronel, outorgado pela população para os que detinham poder econômico e político.

\begin{abstract}
A dinâmica do regime, eletivos os cargos, sobretudo o cargo de governador, leva a deslocar o eixo decisório para os Estados, incólumes os grandes, cada dia mais, à interferência do centro, garantindo-se, fortalecendo-se este com o aliciamento dos pequenos, num movimento que culmina na política dos governadores. Dentro de tal seqüência é que se afirma o coronelismo, num casamento, o regime de bens e relações será necessário determinar com as oligarquias estaduais. ${ }^{1}$
\end{abstract}

O coronel descrito pela historiografia brasileira é alguém de reconhecida influência política local ou regional, representante das oligarquias agrícola-mercantis, detentor de poder político decisório e do latifúndio monocultor. Certamente, o coronel descrito pela historiografia possui um perfil genérico em todo o país. Poucos são os estudos comparativos que possibilitam uma distinção entre os coronéis das zonas de monocultura de exportação, caso específico do nordeste brasileiro, e os coronéis surgidos no Sul do Brasil, onde predominavam as atividades econômicas da pecuária extensiva e extrativismo vegetal. As relações políticas, econômicas e sociais diferem de uma região para outra, caracterizando uma tipologia própria de comportamento coronelístico. O coronel nordestino, mais estudado, mais presente na atividade da lavoura de exportação, tem um perfil bem delineado pela historiografia brasileira.

\title{
O coronelismo, sua influência na região do Contestado
}

As múltiplas facetas do tipo de coronel surgido no sul paranaense e norte catarinense são pouco conhecidas. No estado vizinho do Rio Grande do Sul é bem mais característico e conhecido o coronel, oriundo dos caudilhos rurais, do início do período republicano. As características econômicas da própria região eram diferentes, bem como as relações de trabalho, decorrentes da presença, em maior número, de imigrantes e dos investimentos externos, iniciados na segunda década do período republicano. A própria formação do latifúndio no território sul paranaense e no norte catarinense tem suas origens no Segundo Reinado, fortalecendo-se com a Lei de Terras de 1850 e sedimentandose no início do período republicano.

A região foi ocupada a partir do século XIX. Anteriormente, o território era habitado pelos grupos indígenas Xoclen e Kaingang e alguns poucos habitantes, oriundos do norte ou sul, que se fixaram ao longo do caminho das tropas. Este território foi cortado pelo ca-

\footnotetext{
${ }^{1}$ Faoro, Raimundo (1996). Os donos do poder. São Paulo: Editora Globo.
} 
minho do Viamão que, no século XVIII, representou um importante estímulo para a economia sulina. O transporte de tropas bovinas e muares do sul para Sorocaba, com o intuito de atender as regiões auríferas, estimulou de forma gradativa a ocupação e o povoamento da região. O tropeirismo constituía uma atividade cíclica, pois dependia da demanda de carnes e disponibilidades de tropas no sul. Inicialmente, os tropeiros dispunham do gado nativo, introduzido no sul pelos pregadores jesuítas, como atividade de subsistência para os indígenas.

Com o aumento da demanda de carne e industrialização do charque, o gado vacum passou a rarear, havendo a necessidade de criatórios. Surgem então no Rio Grande do Sul e sul catarinense, os estancieiros, que fincam raízes no território, necessitando mão de obra e investimentos. Os estancieiros, os imigrantes e outros lavradores, conforme ocupavam o território, expulsavam os habitantes nativos - os indígenas. Algumas regiões do território catarinense, a exemplo de Lages e Campos Novos, foram ocupadas por criadores de gado descendentes de fugitivos da Guerra dos Farrapos. E a frente pastoril estende-se até os municípios de Irani e Palmas, na divisa de Santa Catarina e Paraná. Nessa região de pecuária extensiva formam-se grandes fazendas, constituídas por famílias que deram origem aos grandes coronéis, como os Ramos, em Lages; família Raupp, em Campos Novos, Santa Catarina; Araújo Pimpão, em Palmas; e Amazonas Marcondes, em União da Vitória, no Paraná.

O característico coronel foi, por muito tempo, um fazendeiro, possuidor de várias propriedades, em diversos distritos. O coronel fazendeiro era aquele que mais se aproximava do histórico senhor de engenho da antiga sociedade patriarcal. ${ }^{2}$

Até o final do período imperial, os coronéis estavam limitados a um poder local, detentores de grandes posses, com muitos agregados e peões que cuidavam de suas terras e as cultivavam. Com a instauração do regime republicano, o velho mandonismo local dos proprietários de terras assume novas feições. A Constituição republicana de 1891 estabeleceu um regime político de base representativa no Brasil, ou seja, com eleições periódicas para a escolha dos representantes dos poderes legislativo e executivo federais, estaduais e municipais. O poder local do coronel amplia-se, passando esse a conviver com novos mecanismos eleitorais, tornando-se um representante do poder do Estado. Além de reconhecido poder econômico, passa a ser um chefe político local, conseguindo apoio, prestígio e benesses estaduais, na razão direta da capacidade de garantir o apoio eleitoral aos governos estaduais.

\footnotetext{
2 Janotti, M. M. I. (1985). Coronelismo: uma política de compromissos. São Paulo: Brasiliense.
} 
Com a passagem do período imperial para o regime republicano a estrutura político-econômica não sofreu alterações, permanecendo a mesma. Os coronéis fortalecem seu poder político com o novo regime que se instala. Além do fortalecimento político, ampliam sua força econômica.

A Constituição republicana de 1891 outorgou o direito de voto a todo cidadão brasileiro, ou naturalizado, que fosse alfabetizado. Esta nova Carta ampliou juridicamente o direito político da instituição do voto. A nova Carta de 1891 rompeu com a instituição do voto censitário. Juridicamente extintas as barreiras econômicas e políticas existentes até a Constituição de 1891, presume-se que o novo eleitorado poderia livremente escolher seus novos governantes. Na prática, observou-se que o eleitorado da área rural ou urbana continuaria obedecendo aos mandos dos políticos locais. Alargara-se o número de eleitores, mas os chefes políticos locais ou regionais continuariam os mesmos, com um espaço maior de poder político, para eleger seus parentes, ou apaniguados, para as Câmaras, Presidência dos Estados e Senado.

A eleição será o argumento para legitimar o poder, não representando a soberania popular. A fraude, a coerção, a manipulação, a farsa eleitoral irão vilipendiar a soberania popular republicana, estribada na Constituição de 1891. Esta carta magna ampliou o poder político do coronel, na medida em que permitiu aumentar o número de eleitores sob seu controle direto. Aumentando o poder político, aumenta progressivamente sua força econômica, local e regional. Obtém o respeito e o respaldo das oligarquias políticas estaduais, para suas reivindicações, na proporção direta do número de votos que empresta às oligarquias. Há uma perfeita interação entre o coronel e as oligarquias estaduais. O coronel é obediente e leal ao poder estadual, para contar com o apoio financeiro e econômico das oligarquias; elas defendem seus aliados, colocando à disposição os cargos e as milícias estaduais, tendo como contrapartida a proteção e a benevolência destas.

Não se imagine, entretanto, que entre o coronel e o simples eleitor impere a brutalidade, com o bacamarte engatilhado contra o rebelde potencial. O coronel é, acima de tudo, um compadre, de compadrio o padrão dos vínculos com o séqüito. ${ }^{3}$

O grau de sujeição do eleitor sertanejo ao coronel apresenta-se em duas dimensões. A primeira, de dependência econômica do eleitor, em relação ao coronel. A segunda, uma relação de vínculos afetivos de compadrio, que se amoldam culturalmente nas relações, levando à fidelidade do sertanejo eleitor ao seu coronel protetor. Uma instituição, particularmente, tinha uma grande importância para abrandar a imposição da vonta-

\footnotetext{
${ }^{3}$ Faoro, R. (1996). Op. cit.
} 
de do mais poderoso: o compadrio. O sertanejo pobre buscava no batismo uma forma de conseguir a proteção de uma pessoa rica e influente, quase sempre o coronel de quem dependia. As relações de compadrio foram muito fortes e solidamente enraizadas no seio do poder coronelístico. Raymundo Faoro afirma que estas relações suavizavam as distâncias sociais e econômicas entre o chefe e o chefiado.

O batismo estabelece entre o padrinho e afilhado obrigações de parte a parte. 0 eleitor sertanejo, nestas circunstâncias, vota nos candidatos indicados, não por medo, mas como um dever sagrado. A dimensão do dever sagrado de fidelidade ao coronel explica o gesto espontâneo, muito comum do eleitor, mostrando o voto à mesa eleitoral, mesmo dispondo da prerrogativa constitucional do voto secreto. O rompimento da fidelidade e a rebeldia do eleitor sertanejo acontece em certas circunstâncias, quando há descaso do coronel, em relação às amarguras e queixas do eleitor.

Na região do Contestado, este rompimento ou esfriamento dos vínculos afetivos entre o coronel e sertanejo ocorre no final do século XIX e início do século XX, como resultante da penetração, nos sertões, do capitalismo transnacional, de empresas extrativas e colonizadoras. O coronel mantinha um pé no mundo sertanejo, cumprindo os compromissos pessoais, e um pé no mundo dos negócios, em que prevaleciam os interesses econômicos. As relações entre dominantes e dominados eram orientadas por dois princípios opostos: as associações morais (os laços pessoais) e as ligações por interesse.

\section{Sempre que colocado em situação crucial para seus negócios, o proprietário de terras deu prioridade a estes, embora com isto lesasse seus moradores e assim interrompesse a cadeia de compromissos sobre a qual se assentava, em larga medida, o seu poder. Diante da necessidade de expandir seu empreendimento, nunca hesitou em expulsá-los de suas terras. ${ }^{4}$}

Entre os laços pessoais com os sertanejos e seus interesses econômicos, portanto, o coronel sempre priorizou os últimos. Para preservar ou ampliar seus negócios, o coronel não se importava em destruir o paternalismo e as ligações pessoais que mantinha com os sertanejos. A quebra dos vínculos de dependência abre caminho para que, em determinadas circunstâncias, se produzissem enfrentamentos entre os sertanejos e seus antigos protetores, os coronéis. Nestas circunstâncias, o coronel age pela pressão, usa mecanismos coercitivos e, muitas vezes, violentos. Na região do Contestado, em muitas circunstâncias, os coronéis utilizaram os jagunços, cognominados vaqueanos, para expulsar os sertanejos, considerados intrusos e rebeldes. Não é um acaso ser o coronel definido mais

\footnotetext{
${ }^{4}$ Franco, M. S. C. (1987). Homens livres na ordem escravocrata. Rio de Janeiro: Bertrand Brasil.
} 
pelas suas características políticas. O aspecto político é que mais chama atenção na figura do coronel.

A análise do coronel não deve ater-se à faceta política, mais evidente, mas sim, nas múltiplas funções econômicas e sociais que ele exerce, como decorrente do aumento do poder político. Analisar o coronel apenas no aspecto político é empobrecer a análise, impedindo uma compreensão mais ampla desta figura ímpar da história social e política do Brasil.

Um coronel importante constituía assim uma espécie de elemento sócioeconômico polarizador, que servia de ponto de referência para se conhecer a distribuição dos indivíduos no espaço social, fossem estes seus pares ou seus inferiores. $^{5}$

$\mathrm{Na}$ estrutura social visualiza-se com nitidez o espaço e a importância do coronel em determinadas circunstâncias históricas. Os seus apaniguados eram visualizados facilmente, até porque se identificavam e eram identificados como "gente" do coronel "fulano de tal”. Essa identificação situava no espaço econômico e político o indivíduo.

No início do período republicano inaugura-se a política dos governadores, mais precisamente no governo do presidente Campos Sales. Os governadores darão sustentação política ao presidente. Os coronéis serão os grandes aliados dos governadores, mediante uma permanente troca de favores políticos.

A essência do compromisso coronelista, salvo situações especiais que não constituem regra, consiste no seguinte: da parte dos chefes locais, incondicional apoio aos candidatos do oficialismo nas eleições estaduais e federais; da parte da situação estadual, carta branca ao chefe local governista em todos os assuntos relativos ao município, inclusive na nomeação de funcionários estaduais do lugar. ${ }^{6}$

Os governadores dos estados, representantes na maioria das vezes das oligarquias tradicionais, operavam um mecanismo político de troca de votos, pela nomeação de funcionários públicos estaduais e concessão de terras. Confunde-se na esfera privada 0 papel do coronel com o das oligarquias estaduais. Em nível municipal, a sustentação política do prefeito, quando este não fosse um coronel, obedecia a um complexo sistema de clientelismo, com a nomeação de funcionários municipais, favores e preferências na execução de obras públicas. Os dependentes do coronel, parentes, afilhados, agregados e peões estavam obrigados, com o regime republicano, a retribuir os favores de seu protetor, votando nos candidatos que este indicasse. Era o chamado voto de cabresto. Os ser-

\footnotetext{
${ }^{5}$ Queiroz, M. V. (1966). Messianismo e conflito social, a guerra sertaneja - 1912-1916. Rio de Janeiro: Civilização brasileira.

${ }^{6}$ Leal, V. N. (1997). Coronelismo, enxada e voto. Rio de Janeiro: Nova Fronteira.
} 
tanejos, devendo obediência pessoal ao coronel e dele dependendo para sobreviver, seguiam sua orientação nas eleições.

São os fazendeiros e chefes locais que custeiam as despesas do alistamento e da eleição. Sem dinheiro e sem interesse direto, o roceiro não faria o menor sacrifício nesse sentido. Documentos, transporte, alojamento, refeições, dias de trabalho perdidos, e até roupa, calçado, chapéu para o dia da eleição, tudo é pago pelos mentores políticos empenhados na sua qualificação e comparecimento. (....) É, portanto, perfeitamente compreensível que o eleitor da roça obedeça à orientação de quem tudo Ihe paga, e com insistência, para praticar um ato que Ihe é completamente indiferente. ${ }^{7}$

As eleições, mecanismo de representação da vontade popular, transformavam-se em mero exercício do poder pessoal da vontade dos coronéis. A garantia do retorno do investimento, no dia das eleições, era assegurada, através da instituição do voto aberto. Verificando as primeiras Atas das Câmaras Municipais do início do período republicano de alguns municípios sulinos, como Palmas, União da Vitória, Canoinhas, Curitibanos, Campos Novos, entre outros, constatamos que os camaristas, como eram denominados os vereadores, representavam o poder do próprio coronel. Parcela dos camaristas eram funcionários diretos da administração municipal, ou seja, homens de confiança do próprio coronel.

Outro grupo de camaristas, quando não participantes diretos da administração municipal possuíam um grau de parentesco ou compadrio com o coronel. Com isto constatamos que o prefeito legitimava-se como verdadeiro mandão, dispondo sobre tudo e sobre todos. Os dissidentes em relação à forma de pensar e agir do coronel eram excluídos de qualquer possibilidade de ascensão pública, até mesmo de participar do processo eleitoral. O coronel necessitava do voto para manter o controle da política local e demonstrar o seu prestígio junto às oligarquias estaduais. Para tanto, buscava a fidelidade do eleitor com presentes ou pela coerção. Uma forma de coerção muito comum era a presença dos capangas do coronel nos locais de votação. Outra medida coercitiva era a localização das mesas eleitorais, na maioria das vezes, instalada na casa do coronel, de parente ou apaniguado. O que caracterizava as eleições imperiais ou republicanas é a fraude eleitoral sistemática. O que levaria ao ostracismo um coronel era a derrota eleitoral. A vitória deveria ser obtida a qualquer custo, não importando os delitos a serem cometidos.

Encontramos uma referência sobre o coronel Amazonas que, além de proprietário de terras nas áreas rurais e urbanas, foi prefeito da cidade de União da Vitória, município limítrofe com Santa Catarina, região envolvida no movimento do Contestado. Lá só possui bens um donatário feliz, o coronel Amazonas, prefeito eterno, senhor das sesmarias em

\footnotetext{
${ }^{7}$ Ibidem.
} 
derredor, eminência política paranaense. O coronel Amazonas de Araújo Marcondes foi deputado provincial pelo Partido Liberal de 1888 a 1891; disputou a segunda vicepresidência do Estado paranaense, sendo derrotado pelo coronel Olegário Rodrigues de Macedo, para o quadriênio governamental de 1908-1912. Não foi vitorioso pois não era aliado das oligarquias políticas estaduais. Foi prefeito do município de União da Vitória durante um período de 15 anos consecutivos. Percebe-se que tudo girava em torno do poder econômico e político do coronel, que era a figura de atração e irradiação de tudo o que ocorria no campo e na cidade, mantendo um sistema de servidão e clientelismo político.

A primeira Constituição republicana de 1891 estendeu o direito de voto a todo cidadão brasileiro, ou naturalizado, alfabetizado, parecendo assim extintas as barreiras econômicas e políticas, que impediam a maioria da população de participar do processo eletivo. Há um aumento do número de eleitores, alargando, assim, a estrutura eleitoral, permanecendo, no entanto, os mesmos chefes políticos locais e regionais com seu poder político de eleger para as câmaras, para as presidências dos estados e para o senado, seus parentes, protegidos e aliados. Segundo a afirmativa do sociólogo francês Jean Blondel (1957), o coronelismo apresenta-se na sua estrutura hierarquizado em três níveis: "os coronéis; abaixo deles os cabos eleitorais; e, na base de estratificação política, os eleitores". Podemos afirmar que os funcionários municipais e os camaristas são os maiores cabos eleitorais do coronel. Os cabos eleitorais são aqueles que mantêm, e, se necessário, expandem a força do coronel. São eles, portanto, o indispensável elo entre o coronel e a massa do eleitorado.

O poder político de um coronel é diretamente proporcional ao número de eleitores que domina. Coronéis que comandavam um número pequeno de eleitores tinham um poder local, outros que dominavam um eleitorado maior detinham um poder regional. O principal representante sulino do poder coronelístico brasileiro foi Pinheiro Machado. Foi ele, ocupando uma vaga senatorial pelo Rio Grande do Sul, no início do período republicano, com a política dos governadores, o grande articulador nacional. Victor Nunes Leal, descrevendo as práticas eleitorais deste período, bem como o poder do coronel, relata um diálogo de Pinheiro Machado com um jovem correligionário de fidelidade duvidosa: "- Menino, tu não serás reconhecido, por três razões. A terceira é que não foste eleito". Define este autor o coronelismo como sendo uma forma de adaptação entre o poder privado e um regime político de extensa base representativa. A base representativa eleitoral aumenta a partir da Constituição de 1891, sem alargar, para a maioria da população, a possibilidade de eleger representantes que irão defender seus interesses. 
Na região do Movimento do Contestado, em Santa Catarina, encontramos em muitos municípios, como Canoinhas, Curitibanos e Campos Novos, no início do século XX, algumas disputas de poder coronelístico local. Houve chefes políticos maiores e menores, em constantes disputas locais e regionais, pretendendo assumir o mando municipal, ou o apoio da oligarquia estadual. Nessas condições políticas, de grupos antagônicos e rivais, o que poderia ser uma alternativa de múltipla escolha para a população provoca uma permanente instabilidade.

Vivendo nesse espaço, ora de alianças, ora de lutas políticas latentes, ou violentas, a população sertaneja ou citadina torna-se mero instrumento dos interesses dos coronéis. A coexistência dos sertanejos com esses poderes antagônicos municipais, contraditoriamente, não os liberta da subordinação política e econômica. Dessa forma, os coronéis litigantes conseguem falsear a realidade e legitimar, por meio de disputas, a dominação política e econômica sobre a maioria dos sertanejos. O litígio dos coronéis, em nível municipal, estava sempre vinculado a interesses privados do próprio coronel, ou de apaniguados políticos. O coronel alia-se às oligarquias estaduais, ou a um novo processo econômico capitalista que penetra nos sertões catarinenses, desde que possa auferir vantagens políticas ou econômicas para si ou componentes de seu grupo de apoio e sustentação. Os sertanejos não se libertam de uma permanente subordinação aos interesses político-econômicos dos coronéis. Os coronéis detinham uma força coercitiva para fazer valer o seu poder.

Temeroso dos riscos inerentes a ajuntamentos desta natureza, e alarmado pelo fato de que em Taquaruçu reuniram-se homens fiéis a seu inimigo político, o coronel superintendente de Curitibanos decidiu dispersar os sertanejos ameaçando-os com violência. ${ }^{8}$

Ao nível local ou regional, os coronéis dispunham de grande número de jagunços, vaqueanos, agregados e correligionários, para defendê-los num eventual conflito, ou necessidade de expulsão de intrusos incômodos. Estes conflitos, que ocorriam esporadicamente, em nível local ou regional, envolviam questões de ordem política, como expulsão ou eliminação de adversários da região ou de ordem econômica, com a usurpação de terras. A violência explícita dos coronéis, com o início dos ajuntamentos de sertanejos, foi uma tônica permanente na região. A violência estava arraigada na cultura dos coronéis, como decorrência da própria formação de origem rio-grandense e caudilhesca da Guerra dos Farrapos, bem como da Revolução Federalista de 1893. A história tratou de imortalizar estes coronéis e caudilhos, com nomes de escolas, ruas, cidades, etc. Cabe ao histo-

\footnotetext{
${ }^{8}$ Monteiro, D. T. (1974). Um confronto entre Juazeiro, Canudos e Contestado. São Paulo: Duas Cidades.
} 
riador, através da metodologia de pesquisa científica, desmistificar a figura desses heróis, que manipulavam a vontade e os anseios dos sertanejos catarinenses e paranaenses.

A manipulação dos sertanejos pelos coronéis, no movimento do Contestado, ocorreu de forma muito intensa. Manipulação com o objetivo de provocar um coronel adversário e incômodo, mantendo assim certo número de sertanejos aliados e muito próximos. Resolvida a questiúncula com o adversário, os sertanejos eram dispensados e mantidos a distância. No fervor do movimento do Contestado, muitos coronéis arregimentaram os sertanejos engajados no movimento, sertanejos que viviam em outros latifúndios ou mesmo pequenos proprietários e arrendatários, envolvidos diretamente no conflito. Era uma realidade factível, os coronéis sempre dispunham dos sertanejos para atingir intentos que melhor lhes convinham. Nesta dualidade de ação, o sertanejo era, em certo tempo, um trabalhador e defensor leal e, em outro tempo, um jagunço útil.

\section{Confronto de posseiros e vaqueanos na região do Contestado}

Todos os coronéis dispunham, em seu território, de jagunços leais, que serviam para afastar de suas propriedades concorrentes, fossem outros coronéis ou posseiros intrusos. Além dos jagunços, os coronéis dispunham dos vaqueanos, pequenos proprietários, ou sitiantes expropriados, trabalhadores das estradas de ferro abandonados na região, após a conclusão da obra. No auge do movimento de rebeldia encontramos a presença de remanescentes rio-grandenses, da Revolução Federalista. Após o cerco do município da Lapa, Paraná, onde os federalistas, liderados por Gumercindo Saraiva, retornaram derrotados, teriam adentrado o sertão catarinense, por União da Vitória, ali permanecendo escondidos, atuando como vaqueanos.

Segundo o relato de Maurício Vinhas de Queiróz, nas proximidades da Vila Nova do Timbó estabelecera-se o antigo maragato Demétrio Ramos, que reunia em torno de si alguns sertanejos assalariados em armas. Agia por conta de Santa Catarina, de cujo governo recebia recursos de toda a ordem. Por outro lado, na mesma área, o Paraná começou a armar paisanos para reforçar as fileiras de sua força pública. Houve, de parte a parte, ameaças de pilhagens e depredações em fazendas de gado e ervais.

O apoio e recrutamento de vaqueanos era um acontecimento corriqueiro na zona conflagrada. O maragato Demétrio Ramos, em 1905, chegou a ter sob seu comando 600 homens bem armados, mantidos pelo governo catarinense, associado aos comerciantes dos municípios de Canoinhas e Timbó Grande. 
O coronel Fabrício Vieira, sediado no município de Canoinhas, comunicou-se com o Governo Federal, tendo este enviado de Florianópolis um contingente do Exército para apaziguar os ânimos fortemente acirrados. Em 1909, novamente com o apoio das oligarquias catarinenses, o capitão da Guarda Nacional Aleixo Gonçalves de Lima, comandando cerca de 500 homens, civis e policiais catarinenses, invade um território que seria paranaense. Os vaqueanos foram utilizados antes e durante o conflito para preservar as posses do coronel e defender uma zona litigada pelos dois estados. Muitos desses vaqueanos, aproveitando-se do conflito, agiam por conta própria, cometendo atrocidades, crimes sob encomenda e invasão de propriedades.

Essas movimentações de grupos armados, provocados por interesses dos coronéis, comerciantes ou do governo estadual e federal envolvem os sertanejos de forma direta. São os mesmos envolvidos no turbilhão de interesses do poder político e econômico das oligarquias, coronéis e comerciantes. Familiarizam-se com intrigas, manejo de armas, enfim, tudo o que leva a uma cultura de confrontos e embates futuros. O mais famoso julgamento na Comarca do Município de Canoinhas, Santa Catarina, ocorrido em 1915, foi de três vaqueanos: Pedro Leão de Carvalho, vulgo Pedro Ruivo; João de CarvaIho, vulgo João Ruivo; e Nero de Tal.

\begin{abstract}
Pedro Leão de Carvalho, ou antes Pedro Ruivo, nome que está bem vivo no espírito de a população da Comarca, pelas horríveis façanhas cometidas, comandou um piquete de patriotas por ocasião das lutas que se feriram entre os infelizes sertanejos cognominados jagunços e as forças legais. Em sua companhia, sempre andou seu filho João de Carvalho, também conhecido por João Ruivo, e Nero de Tal seu fiel capanga. Seria nobre o procedimento de Pedro Leão de Carvalho, e, bem assim o do seu filho, e de Nero, seu companheiro, se os seus trabalhos em prol da legalidade, fossem um ato de patriotismo. Porém, estes autos nos mostram de uma maneira precisa, categórica, que Pedro João e Nero, envolvendo-se na luta, não alimentavam outra intenção senão de se enriquecerem, muito embora fosse preciso pisarem sobre todas as leis da humanidade, fosse necessário praticarem atos cruéis e mesmo, de uma hediondez sem limites. ${ }^{9}$
\end{abstract}

A denúncia do promotor mostra através da expressão "infelizes sertanejos", os cognominados jagunços, que teriam praticado "atos cruéis". Os coronéis deixavam seus jagunços à própria sorte, uma vez caçados e acossados pelas forças oficiais e maltratados pelos vaqueanos. Os vaqueanos eram contratados pelas forças da legalidade, estavam, portanto, a serviço das oligarquias econômicas e políticas. A área litigiada de longa data entre os dois estados estava infestada de vaqueanos, protegidos e armados pelas oligarquias dos estados litigantes. Os vaqueanos desvirtuam-se do objetivo pelo qual es-

\footnotetext{
${ }^{9}$ Processo Crime de Pedro leão de Carvalho, Pedro Ruivo e João de Carvalho (1915). Arquivo do Fórum do município de Canoinhas - SC.
} 
tavam na área, que era ocupar e proteger uma zona rica em ervais defendendo um ou outro estado.

Passaram a aterrorizar a população da área conflagrada, assaltando propriedades de sitiantes, assassinando sertanejos, estuprando mulheres, enfim, praticando atos de crueldade com a população sertaneja. Muitos dos sertanejos não eram expulsos de suas posses, mas saqueados, o que os levava a uma rebeldia permanente, facilitando o engajamento ao lado dos expropriados. Mediante tal contexto o sertanejo vive um momento mítico monárquico, de paz e tranquilidade, tributando todos os males ao advento do regime republicano.

Com o novo regime republicano, os laços paternalistas existentes entre os sertanejos e os coronéis afrouxam-se de forma significativa e rápida, especialmente após a penetração de forças capitalistas na construção da estrada de ferro, com início em 1908, e instalação de madeireiras, em 1911, na região do conflito. A construção da estrada de ferro provoca a expulsão dos posseiros sertanejos das terras contíguas aos trilhos.

O coronelismo é, sobretudo um compromisso, uma troca de proveitos entre o poder público, progressivamente fortalecido, e a decadente influência social dos chefes locais, notadamente dos senhores de terras. Não é possível, pois, compreender o fenômeno sem referência à nossa estrutura agrária, que fornece a base de sustentação das manifestações de poder privado ainda tão visíveis no interior do país. ${ }^{10}$

O poder do coronel dependia basicamente da sua capacidade de troca entre ele e o poder público, que demonstrava o poder do coronel, em fornecer, politicamente, sustentação eleitoral, através de uma mercadoria chamada voto.

Uma vez confirmadas no controle da administração pública, as oligarquias retribuem o favor dos coronéis, reforçando-Ihes o poder local. Os coronéis da região do Contestado, distanciados dos setores mais próximos e modernos da economia brasileira, portanto, débeis economicamente, tinham apenas um caminho a ser trilhado: aliar-se econômica e politicamente às oligarquias estaduais. O estado, em contrapartida, fornecia os favores financeiros, de justiça, segurança e empregatícios.

Para os coronéis, as novas forças capitalistas eram mais promissoras, levavam a uma nova perspectiva de associação econômica. Os coronéis percebem um novo tempo republicano, que pretende ser modernizador, associam-se ao pensamento das oligarquias, que veem os sertanejos como um empecilho para o desenvolvimento da região do Contestado. Este clima de mudanças estruturais profundas em seu meio provoca uma aceleração na criação de imaginários no meio sertanejo. Esse tempo vivido pelo sertanejo

\footnotetext{
${ }^{10}$ Queiroz, M. V. (1966). Op. cit.
} 
não foi compreendido pelas forças oficiais repressivas. Com o advento do regime republicano, o coronelismo foi uma das evidências de como estava conflitiva a vida social e política na região do Contestado.

Enquanto representante do mandonismo local, o coronel exercia sua influência, paternal se possível e coercitiva se necessário, sobre as camadas mais pobres da população, que vivia freqüentemente como agregada nas terras dos poderosos locais. Deste modo, o coronel prestava um serviço aos políticos estaduais nos períodos eleitorais, arregimentando seus eleitores de cabresto, e esperava em troca os favores da política Estadual para o seu município e sua pessoa. Na relação, entre o poder privado exercido pelos coronéis, ao nível local, e o domínio da política estadual pelas oligarquias residia a substância do compromisso coronelista. ${ }^{11}$

Na região do Contestado, os peões de fazendas e os que viviam da extração da erva-mate eram analfabetos, portanto não votavam. Muitos deles formavam os grupos de capangas ou vaqueanos que os coronéis dispunham para impor sua lei. O trabalho do coronel era o de persuadir os sitiantes, que viviam próximos ao seu latifúndio ou município, e que eram eleitores aptos a votar, mantendo uma relação de barganha com tais sitiantes.

Uma parcela da camada alfabetizada da população encontrava-se entre os artífices, comerciantes e funcionários dos vilarejos e municípios maiores. Estes formavam a grande massa do eleitorado, eram tratados com cordialidade e benesses, ou com opressão e violência. Os coronéis, sempre aliados políticos das oligarquias estaduais, associam-se às novas forças produtivas que penetram no sertão catarinense, usurpando e expropriando os sertanejos de suas posses.

A exclusão do sertanejo de suas posses foi muito intensa nas áreas contíguas aos trilhos da estrada de ferro São Paulo-Rio Grande do Sul. Nesses locais, sertanejos perambulavam pela região em grupos, sem um território que thes pudesse servir de abrigo. Os coronéis e a companhia que construía a estrada de ferro viam-nos como intrusos de risco. O ajuntamento dos sertanejos estava intimamente ligado à exclusão de sua terra. Os principais ajuntamentos de sertanejos ocorreram em Taquaruçu, Caçadorzinho, Timbó Grande, locais próximos à ferrovia. Estes ajuntamentos aumentaram com o ingresso dos trabalhadores da ferrovia, ali abandonados após a conclusão da obra. Submetidos a tal violência, buscaram o sustentáculo na formação de irmandades e na prática religiosa, matizada na pregação e ensinamentos dos monges.

Em algumas regiões, envolvidas direta ou indiretamente com o movimento do Contestado, observa-se o papel ambíguo exercido pelos coronéis. Esta ambiguidade manifestou-se em alguns momentos na região de Curitibanos, onde havia dois coronéis adversá-

${ }^{11}$ Silva, L. M. A. (1990). A Lei da terra. São Paulo: PUC. 
rios, um ligado às oligarquias, o outro com estreita ligação aos sertanejos e sem o apoio das oligarquias estaduais. Este último submeteu-se ao poder das forças oficiais que combatiam os sertanejos. Na região de Canoinhas, o coronel Fabrício Vieira coloca um número significativo de vaqueanos a serviço das forças oficiais repressoras para combater os ajuntamentos sertanejos. Os ajuntamentos sertanejos preocupavam os coronéis, gerando desconfianças e vários pretextos para serem atacados.

No ano de 1897, próximo ao município de Lages, um curandeiro reúne um grande número de sertanejos, fazendo pregações e impondo penitências. Argumentando que esses fanáticos estavam roubando gado e promovendo desordens, o coronel Vidal de Oliveira Ramos partiu de Florianópolis, com uma milícia policial, para atacar os sertanejos. Com o devido apoio de outro coronel do município de Campos Novos, bem como de um contingente de policiais gaúchos, reprimem, dispersando e matando, os sertanejos. Até mesmo seus ranchos foram queimados.

Segundo relatos do período, os coronéis e as oligarquias temiam que se repetisse, em sua área, o drama de Canudos. As páginas de poucos jornais que circulavam entre os coronéis e as oligarquias àquela época desencadearam um grande temor a qualquer ajuntamento de sertanejos. Permanecia o medo, estigmatizando o risco de novos canudos. Na memória da classe dominante estava ainda vivo o que ocorrera, um ano antes, nos sertões baianos. Na região do município de Palmas, território paranaense limítrofe ao estado catarinense, ocorre um ajuntamento de sertanejos originários do território catarinense. Este ajuntamento foi atacado pelas tropas oficiais paranaenses, mesmo tendo seu comandante recebido um pedido de intercessão de parte do coronel Araújo Pimpão, que não vislumbrava riscos, apenas perdas políticas e humanas com o ataque aos sertanejos.

A ambiguidade em que se vê envolto o coronel é decorrente de seus interesses imediatos e circunstâncias políticas e econômicas. Interesses, ora simpáticos aos sertanejos, como o ocorrido com o coronel Henriquinho, na região de Curitibanos, ou favoráveis às forças repressoras, do coronel Fabrício Vieira, em Canoinhas. A ambigüidade em que vivem os coronéis é diretamente proporcional ao crescimento de antagonismos entre 0 poder local, exercido pelos mesmos, e o poder oficial, exercido pelas oligarquias. Os sertanejos estão inseridos nesse contexto, como uma clientela passiva, que recebe as transformações econômicas, ocasionadas pela penetração do capital estrangeiro e as mudanças das relações políticas entre os coronéis e as oligarquias.

Há também uma mudança social significativa, com a presença cada vez maior dos imigrantes, interessados em ocupar um espaço vazio de terras devolutas, que serão adquiridas e legalizadas. Muitas destas posses que foram legalizadas eram ocupadas de 
longa data pelos sertanejos. As relações sociais, aparentemente harmônicas entre coronéis, oligarquias e sertanejos, se abalam com o ingresso no sertão de forças transnacionais. Estava sendo construída uma nova realidade social no meio sertanejo, na qual os coronéis incorporam e inserem-se no novo contexto político-econômico. Nessa nova realidade social, o sertanejo é excluído, na distribuição de papéis e funções sociais. Os laços paternalistas existentes entre os sertanejos e os coronéis debilitaram-se gradativamente. As novas forças capitalistas que haviam penetrado na região traziam novas e promissoras possibilidades de ganhos para os coronéis. O sertanejo defronta-se com uma nova realidade excludente, que o leva a pensar em seu mundo idílico, ou passado mitificado.

Nas regiões nas quais havia disputas de poder entre famílias coronelísticas, a exemplo de Curitibanos, as lutas políticas são mais agressivas. São lutas, ora latentes, ora violentas, pelas disputas do poder local. O confronto permanente entre o coronel da situação e da oposição deixa o sertanejo exposto à manipulação de interesses políticos, ora pela situação ora pela oposição. Na maioria das localidades catarinenses inseridas no conflito do Contestado não havia disputas de famílias, havendo uma família com o poder absoluto, vinculada politicamente ao situacionismo estadual.

A região que envolvia a questão de limites entre o Paraná e Santa Catarina foi de permanente instabilidade e risco para os sertanejos que ali viviam. Instabilidade provocada por questões políticas de divisas, que se prolongavam por mais de cinco décadas. A disputa pelo território obrigava os dois estados a disponibilizarem forças policiais e a aliciar vaqueanos, para defender seus interesses. Os sitiantes foram atacados e expulsos, buscando guarida no latifúndio dos coronéis, mas estes não permitiram o corte de seus ervais, deixando o sertanejo a mercê da falta de trabalho. Há uma ruptura nos laços de confiança, entre o coronel e o sertanejo, tendo este último perdido seu paradigma.

A região do Contestado, ao final do século XIX e início do século $X X$, intensificava seu crescimento econômico com a exportação de erva-mate e madeira, atividades típicas das regiões norte catarinense e sul paranaense. Ao sul catarinense e noroeste paranaense havia um crescente aumento dos rebanhos bovinos, que serviam para corte e fabricação do charque, que, juntamente com o charque do Rio Grande do Sul, encontrava um consistente e crescente mercado consumidor. A 'modernidade' econômica nesse período traz grandes levas de imigrantes que se fixam nessas regiões, possibilitando $o$ aumento da população rural e citadina.

A construção da estrada de ferro ligando São Paulo ao Rio Grande do Sul, passa pelo território contestado. Para suprir a mão de obra na construção da ferrovia são utilizados trabalhadores de outras regiões do país, que se fixam após a conclusão da obra. Fa- 
rão parte, juntamente com os sertanejos expulsos de suas terras, de um contingente de errantes.

A presença do capital transnacional, com a exploração da madeira e projetos de colonização agrega-se às mudanças que estavam acontecendo. O coronel associa-se direta ou indiretamente a todas essas mudanças, fortalecendo seu poder econômico. As novas forças econômicas estabelecendo na região novas relações de trabalho associamse ao poder do coronel, aliado político das oligarquias estaduais. O poder coronelístico, um poder conservador, vinculado à propriedade da terra, vislumbra novas perspectivas de vantagens econômicas. Há um rompimento dos laços que aproximavam coronel e sertanejo, mesmo sempre existindo uma diferença de escala econômica. Este rompimento irá intensificar a instabilidade política e social, que conduzirá o sertanejo à rebeldia.

Estudos mostram, ao final do Movimento do Contestado, em 1916, com a derrota dos sertanejos, associada a uma nova mudança da lei eleitoral tirando das câmaras municipais o alistamento dos eleitores e a apuração das eleições, o enfraquecimento do poder dos coronéis. O enfraquecimento paulatino do poder coronelístico está associado a uma diversidade de fatores locais e regionais. Na região do Contestado, os coronéis, débeis economicamente, não estavam vinculados a uma economia agroexportadora, como em outras regiões do Brasil. Suas bases econômicas estavam assentadas no extrativismo da madeira, erva-mate e pecuária, que abrem espaço para novas forças econômicas, grupos transnacionais e de imigrantes que ocupam, gradativamente, o poder econômico local e regional.

No Brasil o auge da sedimentação do poder coronelístico deu-se no período da República Velha, iniciando, a partir daí, sua decadência. Conforme estudos regionais, o declínio do poder dos coronéis na região do Contestado ocorreu nas duas primeiras décadas do período republicano. Terminada a guerra do Contestado, a principal atividade econômica da região continuaria sendo ainda o extrativismo da madeira e da erva-mate, atividades executadas por grupos transnacionais e imigrantes. Nas regiões de Lages e Caçador, cidades catarinenses, instalam-se madeireiras do Rio Grande do Sul. Nas regiões de Canoinhas, Três Barras, Calmon e Matos Costa, instala-se a Lumber, subsidiária do Sindicato Farqhuar. As novas forças econômicas que emergem, estabelecendo novas relações de trabalho, irão minar e diluir o poder do coronel. Os imigrantes irão estabelecer novas formas de contratos de trabalho.

É inegável que alguns coronéis associam-se às novas forças econômicas. Os infortúnios dos sertanejos aumentam com a presença, cada vez maior, do imigrante. 
A situação dos pobres do campo no fim do século e mesmo em pleno século XX não se diferencia daquela de 1856. Era mais do que natural, era legítimo, que esses homens sem terra, sem bens, sem direitos, sem garantias, buscassem uma saída nos grupos de cangaceiros, nas seitas dos fanáticos, em torno dos beatos e conselheiros, sonhando a conquista de uma vida melhor. ${ }^{12}$

Fruto de exclusão e de abandono, o sertanejo reage, busca o sustentáculo para suas ações no misticismo dos monges, como forma de protesto social. $\mathrm{O}$ afrouxamento dos laços que ligam o sertanejo ao coronel e a chegada do estranho levam-no à rebeldia e ao confronto.

\section{Processo}

Processo Crime de Pedro leão de Carvalho, Pedro Ruivo e João de Carvalho (1915). Arquivo do Fórum do município de Canoinhas - SC.

\section{Referências Bibliográficas}

Faoro, Raimundo (1996). Os donos do poder. São Paulo: Editora Globo.

Franco, M. S. C. (1987). Homens livre na ordem escravocrata. Rio de Janeiro: Bertrand Brasil.

Janotti, M. M. I. (1985). Coronelismo: uma política de compromissos. São Paulo: Brasiliense.

Leal, V. N. (1997). Coronelismo, enxada e voto. Rio de Janeiro: Nova Fronteira.

Monteiro, D. T. (1974). Um confronto entre Juazeiro, Canudos e Contestado. São Paulo: Duas Cidades.

Queiroz, M. V. (1966). Messianismo e conflito social, a guerra sertaneja - 1912-1916. Rio de Janeiro: Civilização brasileira.

Silva, L. M. A. (1990). A Lei da terra. São Paulo: PUC.

\footnotetext{
${ }^{12}$ Facó, R. (1998). Cangaceiros e fanáticos. Rio de Janeiro: Bertrand Brasil.
} 